\title{
CURATIVE AND PROPHYLACTIC CONTROL OF FUNGAL LEAF ROT COMPLEX IN ROOT (WILT) AFFECTED COCONUT PALMS IN INDIA
}

\author{
By \\ N. Srinivasan \& M. Gunasekaran ${ }^{1}$
}

\begin{abstract}
Root wilt disease (RWD) is a debilitating malady of coconut in India that is caused by phytoplasma. In RWD affected palms, leaf rot disease (LRD) is commonly superimposed. The LRD is due to fungi and this leaf rot phase forms an integral part of RWD complex. Control of LRD is important as it severely disfigures the palm and brings about rapid deterioration in its health and productivity. Control trial involving Phytosanitation of young leaves, pouring of broad spectrum systemic fungicide, Contaf 5 E (Hexaconazole 5\% EC) into the axil of spindle leaf besides a number of other measures was conducted to study their ameliorating effect on LRD. Prophylactic control trial, especially with the broad-spectrum fungicides was also conducted. Pouring of Contaf into the axil of spindles along with phytosanitory measures on the spindle and other young leaves significantly reduced the incidence of LRD in newly emerging spindles effecting cure. Application of the fungicide on RWD palms prior to the onset of LRD, offered prophylactic protection to emerging leaves against LRD. Relevance of practising integrated control measures, cure of LRD at an early stage itself, the need for strict adoption of crop management technology etc. for effective disease control are highlighted here.
\end{abstract}

\section{INTRODUCTION}

Coconut root (wilt) disease (RWD), caused by phytoplasma (Solomon et.al., 1999; Srinivasan, 1999), occurs predominantly in southern districts of Kerala state, India. In about $65 \%$ of RWD affected palms the leaf rot disease (LRD) occurs superimposed. The RWD affected palms can be identified more easily with the onset of LRD and these diseases are interrelated (Srinivasan, 1991). The spindle leaf (youngest emerging one) of RWD affected palm is invariably weak as compared to spindle of healthy palms. Early symptoms of LRD - spots, lesions etc. - appear in such weakened young leaves, that would coalesce leading to extensive rotting of the soft tissues. Other features of the disease symptom include severe rotting at the distal end of the leaf; lesion development on the unopened lamina, midribs/petioles; lesions being limited to the young and not yet grown leaves; successive infections; vulnerability of palms irrespective of age; severity of the disease during monsoons etc. (Menon and Nair, 1951; Srinivasan and Gunasekaran, 1992; Srinivasan et.al., 1995). The LRD has a complex fungal etiology; in recent years, role of various fungi in the disease have been studied in detail (Srinivasan and Gunasekaran, 1993, 1994 a, b, 1995, 1996 a, b, c, 1998a, 1999a; Srinivasan et.al., 2002). Incidence of RWD-LRD has been observed now in Tamil Nadu state also (Srinivasan et.al., 2000; Srinivasan and Sasikala, 2001).

Management of leaf rot had been an integral part in the management of RWD complex. Various measures for the control of LRD had been formulated since the 1950s by different workers mainly using fungicides (Srinivasan et.al., 1998; Srinivasan and Gunasekaran, 1999b; Koshy, 1999, 2000). Application of fungicides was done through spraying, which is a cumbersome method, considering the height of the palm and the necessity for spraying the entire canopy. As spindle leaf is the vulnerable part for leaf rot infection a strategy was evolved to protect these from the pathogens. Moreover survival of the pathogens in older leaves was generally poor as compared to their activity in the young leaves. Srinivasan and Gunasekaran (1996d) reported encouraging results

1 Central Plantation Crops Research Institute, Regional Station, Kayangulam, Krishnapuram - 690 533, India. 
in emerging leaves by a simple technique of applying fungicides - pouring into axil of the spindle. In continuation of such a study, the possibility of curative and prophylactic control of LRD was experimented by refinement of technology. Hence in this paper, the result obtained from field trials is reported.

\section{MATERIALS AND METHODS}

In vitro evaluation of fungicides indicated the potential of a systemic - broad-spectrum fungicide, Contaf 5E (Hexaconazole 5\% EC) (Srinivasan and Gunasekaran, 1998b). Field control trials were conducted using the fungicide along with other measures in the experimental farm of CPCRI - Regional Station, Kayangulam, India for about three years.

Twenty five year old palms with symptoms of RWD alone and RWD with LRD were separately marked. Per cent of leaves infected with LRD in the later category was worked out and using the disease index (DI) for leaf rot, quantified the extent of damage (Srinivasan and Gunasekaran, 1996d).

\section{Experiment 1}

The pre-treatment DI of palms (LRD) was analyzed and the palms distributed among treatments in such a manner that the mean DIs among the treatments are closer as far as possible (16.4 - 16.9). The disease intensity among palms ranked from mild to moderate level. The palms were numbered treatment wise; spindle leaf of each palm indelibly marked with red paint for regular monitoring of subsequently emerging ones.

The treatments as follows.

\begin{tabular}{|l|l|c|}
\hline $\begin{array}{c}\text { Sl. } \\
\text { No. }\end{array}$ & \multicolumn{1}{|c|}{ Treatment } & $\begin{array}{c}\text { Fungicide concentration Used } \\
\text { (1 liter of suspension/palm) }\end{array}$ \\
\hline 1 & $\begin{array}{l}\text { Phytosanitation (Cutting and removal of rotten portion of only } \\
\text { the spindle and few fully opened leaves in the inner whorl) }\end{array}$ & \multicolumn{1}{c|}{$0.4 \%$} \\
\hline 2 & $\begin{array}{l}\text { Contaf 5E pouring into the axil (cavity around the base) of the } \\
\text { spindle leaf }\end{array}$ & \multicolumn{1}{|c|}{} \\
\hline 3 & Phytosanitation plus Contaf 5E pouring (as described above) & -- Do -- \\
\hline 4 & Contaf 5E spraying (on the leaves in the crown) & -- Do -- \\
\hline 5 & Phytosanitation plus Contaf 5E spraying (as described above) & -- Do -- \\
\hline 6 & $\begin{array}{l}\text { Sequential spraying of fungicides in series as below } \\
\text { (one/round): } \\
\text { Bordeaux mixture } \\
\text { Dithane M-45 } \\
\text { Fytolan }\end{array}$ & $0.1 \%$ \\
\hline 7 & Control (No treatment) & $0.5 \%$ \\
\hline
\end{tabular}

Suspension of relevant fungicide in clean water was prepared afresh at each round of treatment application; a schedule of three times a year (April/May; September; December/ January) was followed. The initial round of treatment was given in April 1996 and there were 10 replications/ treatment.

\section{Experiment 2:}

This experiment was designed to evolve prophylactic control measure for LRD. The RWD affected palms (mostly at early stage of root wilt and free from LRD) were marked as described 
earlier and grouped under two categories as below. Plot size was single palm and replications were 25 .

A Contaf 5E pouring (as detailed earlier @ $4 \mathrm{ml} / \mathrm{litre} /$ palm/round).

B: Control (No treatment).

The number of leaves that had contracted LRD and grading of palms under Experiment 1 were recorded prior to the imposition of treatments. The per cent of leaves that had contracted LRD and DI for successively emerged leaves (after pre-treatment) in palms at each round (in a cumulative manner) was calculated from subsequent observations. The palms under Experiment 2 were also monitored for the incidence of LRD. DI for concerned palms was worked out, when LRD appeared in these palms. Both Experiments were continued till all the leaves in the crown were completely replaced with newly emerged leaves after the start of the Experiments. The data were suitably analyzed for assessing the effect of treatments on LRD.

\section{RESULTS AND DISCUSSION}

The results such as per cent of leaves that have contracted LRD and the disease indices at different stages under the Experiment 1 are presented in Tables 1 and 2, respectively.

The incidence of LRD was least in the treatment - Phytosanitation plus Contaf pouring $(19.1 \%-28.2 \%)$ with a mean of $25.6 \%$ of the emerged leaves only contracting the disease. Appearance of LRD in other treatments, although significantly less than in control palms, it remained at a higher level than in the former treatment. In control palms, the disease occurrence was consistently higher with $69 \%$ of the emerged leaves getting affected. In the treatment Phytosanitation plus Contaf pouring, the DI was also lesser $(6.6-10.6)$ with a mean DI of 8.2 for the emerged leaves. The DIs for palms under other treatments was generally less than in the control, which recorded the highest, mean DI of 24.5. The mean per cent of infected leaves among the treatments, which ranged between 52.8 to 61.0 at pre-treatment level, now stood widely $(28.0$ 74.0) at the final round, the least being in the treatment-Phytosanitation plus Contaf pouring. A similar trend was observed with the DIs of various treatments, least being with Phytosanitation plus Contaf pouring (8.4). In control palms, the disease level shot up from $58.1 \%$ to $74.0 \%$. The DI also for control had increased from 16.7 to 27.2 at the final round. The analysis by covariance technique taking the pre-treatment value as covariate showed that the treatment differences (per cent leaves infected and DI) are significant. The differences in per cent of leaves infected, as well as DI between rounds were only marginal and not significant. Leaf rot incidence and intensity were thus reduced in newly emerged leaves due to various treatments as compared to the disease status in control palms. However, the maximum prevention or suppression was achieved in case of Phytosanitation plus Contaf pouring. This treatment had the benefit of highest mean disease avoidance (by 62\%) and lowering disease intensity (by 69.1\%) over control; at final round the effect was $62.9 \%$ and $66.5 \%$ respectively over control.

The effect of prophylactic treatment over the incidence of LRD at different rounds is presented in Table 3. In Contaf pouring, only 4 out of 25 palms contracted the disease as compared to 9 out of 25 control palms during the course of the Experiment. The disease recurrences in the fungicide - treated palms seemed to be less frequent, erratic and disease intensity was also less; where as, in control palms the tendency of disease recurrence was relatively stronger. At the final round the mean DIs for LRD affected palms stood at 2.3 and 20.8 in the fungicide treated and control, respectively. The results have thus established the possibility of prophylactic control of LRD through the application of the fungicide.

Since early 1950s (Menon and Nair, 1951) beneficial effect of fungicides in the control of LRD has been reported. However, inconsistency in obtaining desirable results, failure in preventing the disease etc. were not uncommon experiences. The practice of removal of infected (young) leaves (Varghese, 1934) for aiding the LRD affected palms to recover could be noted with interest. 
It is pertinent to recall that the focus of infection by the leaf rot pathogens is young leaves, specially the spindles. Therefore, protection of the emerging spindle leaves is logical and strategic. Direct application of fungicide into the axil of the spindle yielded first encouraging results (Srinivasan and Gunasekaran, 1996d). However, measures such as adoption of Phytosanitation (roguing infected young leaves - spindle and few others in the inner whorl, if found infected) to reduce pathogen(s) inoculum/ inoculum potential in situ, use of broad - spectrum systemic fungicides, consistency in the methodology of evaluation etc. were advocated for effecting better control of LRD (Srinivasan and Gunasekaran, 1996d, 1999b). Application of Contaf, a broad - spectrum systemic fungicide (Srinivasan and Gunasekaran, 1998b) into the axil of spindle along with Phytosanitation measures resulted in the cure of LRD palms to a significant extent as the fresh disease incidence/intensity in emerged leaves became lesser. Application of the fungicide into the axil of spindle in (RWD) palms also offered a measure of prophylactic protection to the young leaves against the initial onset of LRD.

It may be noted that LRD forms a part of RWD complex. The RWD affected palm as such systemically suffers due to phytoplasmal infection and the affected palm is weakened. With the technology available as of now, the RWD cannot be prevented effectively or cured. Incidence of LRD in RWD palms compounds the problem. Hence the management of RWD complex in the disease endemic region through the control of leaf rot and judicious adoption of sound agronomic measures, nutrition etc. (to counter the state of plant sickness) is essential for crop sustenance (Srinivasan, 2001, 2002). The loss due to RWD complex could be minimised if LRD is taken care of. Therefore, control of LRD by protection measures along the results gained now becomes more important. An integrated approach including LRD preventive - cum - curative measures, (early stage itself) along with other sound - regular crop management technology (to keep - up the palm vigour) since beginning of the crop culture would be helpful in reducing the crop loss significantly and further a systems approach would go a long way in coconut cultivation in the disease affected regions.

\section{ACKNOWLEDGEMENT}

The authors thank the Director, C.P.C.R.I., Kasaragod; Head of Regional Station; Head of Division of Crop Protection - for facilities and interest on this study. The help rendered by Mr. Jacob Mathew, Principal Scientist, for data analysis, is duly acknowledged. 


\section{REFERENCES}

Koshy, P.K. (1999). Root (wilt) disease of coconut. Indian Phytopatho-logy 52 (4) : 335 - 353.

Koshy, P.K. (2000). Leaf rot disease of coconut. Indian Coconut Journal 31 (2) : 4-10.

Menon, K.P.V. and U. K. Nair (1951). Scheme for the investigation of the root and leaf diseases of the coconut palm in South India. Consolidated final report of the work done from $8^{\text {th }}$ March 1937 to $31^{\text {st }}$ March 1948. Indian Coconut Journal 5 (2): 81-100,113.

Solomon, J.J., C.P.R. Nair, N. Srinivasan, M. Gunasekaran and M. Sasikala (1999). Coconut root wilt - the malady and remedy. Journal of plantation Crops 27 (2): 71-92.

Srinivasan, N (1991). Occurrence of coconut leaf rot in relation to root (wilt) disease. Indian Coconut Journal 21 (10): $14-18$.

Srinivasan, N (1999). Know about phytoplasma as pathogen in relation to coconut diseases and with reference to root wilt. Indian Coconut Journal 30 (7): 3-6.

Srinivasan, N (2001). Diseases and disorders of coconut and their management. In: Plant Pathology (Ed: Trivedi, P. C.), Pointer Publishers, Jaipur, India, pp. 194-254.

Srinivasan, N (2002). Coconut leaf rot complex and perspectives for the disease control - Status report. Indian Coconut Journal 32 (9): 2-9 (Article reproduced in The Planter 78 (913): 203216).

Srinivasan, N. and M. Gunasekaran (1992). An appraisal of symptom expression in coconut due to leaf rot disease. Indian Coconut Journal 23 (10): 2-7.

Srinivasan, N. and M. Gunasekaran (1993). Fungi associated with leaf rot disease of coconut. Indian Coconut Journal 23(10): 2-7.

Srinivasan, N. and M. Gunasekaran (1994a). Identification of Colletotirichum gloeosporioides, Exserohilum rostratum and Gliocladium vermoeseni associated with leaf rot disease of coconut in India. CORD 10 (1): 34 - 50.

Srinivasan, N. and M. Gunasekaran (1994b). Additional fungi associated with leaf rot disease of coconut in India. The Philippine Journal of Coconut studies 19 (2): 26-27.

Srinivasan, N. and M. Gunasekaran (1995). Cylindrocladium scoparium in relation to leaf rot disease of coconut. Indian Phytopathology 48 (2) : 196 - 198.

Srinivasan, N. and M. Gunasekaran (1996a). Coconut leaf rots intensity and fungal incidence. Indian Coconut Journal 26 (9) : 10 - 13.

Srinivasan, N. and M. Gunasekaran (1996b).Pathogenicity of preponderant fungi associated with leaf rot disease of coconut. Indian Coconut Journal 27 (3): 2 - 4.

Srinivasan, N. and M. Gunasekaran (1996c). Incidence of fungal species associated with leaf rot disease of coconut palms in relation to weather and the stage of lesion development. Annals of Applied Biology 129 (3): 433 - 449.

Srinivasan, N. and M. Gunasekaran (1996d). Field control of leaf rot disease of coconut with fungicides. CORD. $12(2): 34-42$. 
Srinivasan, N. and M. Gunasekaran (1998 a). Etiology and recurrence of coconut leaf rot with special reference to seedlings. In : Abstracts of papers, PLACROSYM XIII, pp. 54 - 55, 1998 (Ed. Muraleedharan, N.), UPASI, India, 63 pp.

Srinivasan, N. and M. Gunasekaran (1998b). In vitro assay of fungicides against preponderant fungi of leaf rot disease of coconut palms. Pestology 22 (3) : 17 - 23.

Srinivasan, N. and M. Gunasekaran (1999a). Fusarium solani and Fusarium moniliforme in coconut leaf rot disease. Indian Phytopathology 52 (2) : 160 - 162.

Srinivasan, N. and M. Gunasekaran (1999b). Coconut leaf rot disease complex - A review. CORD $15(1): 33-65$.

Srinivasan, N., M. Gunasekaran and Alka Gupta (2002). Substantive evidences of complex fungal etiology of coconut leaf rot disease. Indian Coconut Journal 32 (12): 12-15.

Srinivasan, N., M. Gunasekaran, T.Joseph and T.S.S Rawther (1998). Leaf rot disease. In : Coconut root (wilt) disease, pp. 83 - 95, 1998 (Eds. Nampoothiri, K.U.K. and P.K. Koshy), CPCRI, Kasaragod, India, 124 pp.

Srinivasan, N., M. Gunasekaran, Rohini Iyer, R. Chandramohanan and M. Kochu Babu (1995). Mycoflora of leaf rot affected coconut palms. Indian Phytopathology 48 (1) : 93 - 95.

Srinivasan, N., P.K. Koshy, P.G. Kamalakshy Amma, M. Sasikala, M.Gunasekaran and J.J. Solomon (2000). Appraisal of the distribution of coconut root wilt and heavy incidence of the disease in Cumbum Valley of Tamil Nadu. Indian Coconut Journal 31 (1): 1-5.

Srinivasan, N. and M. Sasikala (2001). Spread and distribution of coconut root (wilt) disease in the region of Theni - Dindigul districts of Tamil Nadu. Indian Coconut Journal 31 (11): 7-11.

Varghese, M.K. (1934). Diseases of the coconut palm. Department of Agriculture and Fisheries, Travancore, $105 \mathrm{pp}$. 
Table 1. Leaf rot incidence in palms at pre-treatment level and in cumulatively emerged leaves after the initiation of Experiment 1*

\begin{tabular}{|c|c|c|c|c|c|c|c|c|c|c|c|}
\hline \multirow{2}{*}{$\begin{array}{l}\text { SI. } \\
\text { No. }\end{array}$} & \multirow[b]{2}{*}{ Treatment $^{\text {** }}$} & \multirow{2}{*}{$\begin{array}{c}\% \text { of leaves } \\
\text { infected at pre- } \\
\text { treatment (April, } \\
1996)\end{array}$} & \multicolumn{8}{|c|}{$\%$ of emerged leaves showed leaf rot in different rounds } & \multirow{2}{*}{ Mean \% a } \\
\hline & & & $\begin{array}{l}\text { Sep., } \\
1996\end{array}$ & $\begin{array}{l}\text { Dec., } \\
1996 \\
\end{array}$ & $\begin{array}{l}\text { May, } \\
1997 \\
\end{array}$ & $\begin{array}{l}\text { Sep., } \\
1997\end{array}$ & $\begin{array}{l}\text { Dec., } \\
1997 \\
\end{array}$ & $\begin{array}{l}\text { May, } \\
1998 \\
\end{array}$ & $\begin{array}{l}\text { Sep., } \\
1998 \\
\end{array}$ & $\begin{array}{l}\text { Dec., } \\
1998^{b} \\
\end{array}$ & \\
\hline 1 & Phytosanitation & 60.1 & 40.0 & 34.8 & 35.5 & 34.4 & 38.3 & 41.5 & 40.3 & 43.2 & 38.5 \\
\hline 2 & Contaf-pouring & 55.3 & 37.5 & 38.3 & 42.3 & 42.9 & 42.8 & 43.2 & 44.1 & 43.8 & 41.9 \\
\hline 3 & Phytosanitation + Contaf-pouring & 52.8 & 28.0 & 21.9 & 19.1 & 25.9 & 25.7 & 27.8 & 28.2 & 28.0 & 25.6 \\
\hline 4 & Contaf-spraying & 60.9 & 42.0 & 31.4 & 36.4 & 37.0 & 37.4 & 39.4 & 39.8 & 38.4 & 37.7 \\
\hline 5 & Phytosanitation + Contaf-spraying & 61.0 & 66.5 & 54.0 & 37.4 & 32.7 & 34.5 & 37.2 & 36.6 & 36.8 & 42.0 \\
\hline 6 & Sequential spraying & 60.8 & 44.5 & 50.6 & 56.9 & 62.7 & 63.7 & 60.3 & 62.0 & 61.5 & 57.8 \\
\hline 7 & Control & 58.1 & 60.5 & 60.7 & 66.1 & 69.9 & 71.6 & 74.2 & 74.7 & 74.0 & 69.0 \\
\hline \multicolumn{2}{|c|}{ Mean \% } & 58.4 & 45.6 & 41.7 & 42.0 & 43.7 & 44.8 & 46.2 & 46.5 & 46.5 & \\
\hline
\end{tabular}

"Mean of 10 palms/treatment. " See text for details of treatments. a - C.D. $(P=0.01)$ for treatments: 9.2. $b$ - Analyzed using the analysis of covariance technique taking the pre-treatment value as the covariate: Differences in treatment significant (C.D. $=21.9)$. 
Table 2. Leaf rot intensity (disease index) in palms at pre-treatment level and in cumulatively emerged leaves after the initiation of Experiment $1^{*}$

\begin{tabular}{|c|c|c|c|c|c|c|c|c|c|c|c|}
\hline \multirow{2}{*}{$\begin{array}{l}\text { Sl. } \\
\text { No. }\end{array}$} & \multirow{2}{*}{ Treatment ** } & \multirow{2}{*}{$\begin{array}{l}\text { DI of palms at } \\
\text { pre-treatment } \\
\text { (April, 1996) }\end{array}$} & \multicolumn{8}{|c|}{ Disease index (DI) of emerged leaves in different rounds } & \multirow{2}{*}{$\begin{array}{c}\text { Mean } \\
\text { DI a }\end{array}$} \\
\hline & & & $\begin{array}{l}\text { Sep., } \\
1996\end{array}$ & $\begin{array}{l}\text { Dec., } \\
1996\end{array}$ & $\begin{array}{l}\text { May, } \\
1997\end{array}$ & $\begin{array}{l}\text { Sep., } \\
1997\end{array}$ & $\begin{array}{l}\text { Dec., } \\
1997 \\
\end{array}$ & $\begin{array}{l}\text { May, } \\
1998\end{array}$ & $\begin{array}{l}\text { Sep., } \\
1998\end{array}$ & $\begin{array}{c}\text { Dec., } \\
1998{ }^{b}\end{array}$ & \\
\hline 1 & Phytosanitation & 16.4 & 17.5 & 17.9 & 17.0 & 17.2 & 16.9 & 18.4 & 17.8 & 17.2 & 17.5 \\
\hline 2 & Contaf-pouring & 16.4 & 14.0 & 14.5 & 14.5 & 14.2 & 13.7 & 15.8 & 15.2 & 15.3 & 14.6 \\
\hline 3 & Phytosanitation + Contaf-pouring & 16.6 & 10.6 & 8.5 & 6.6 & 7.8 & 7.6 & 8.2 & 8.0 & 8.4 & 8.2 \\
\hline 4 & Contaf-spraying & 16.9 & 20.3 & 16.4 & 18.5 & 17.2 & 16.7 & 18.2 & 16.7 & 17.2 & 17.6 \\
\hline 5 & Phytosanitation + Contaf-spraying & 16.8 & 22.3 & 17.8 & 14.3 & 14.8 & 14.0 & 17.6 & 17.2 & 16.5 & 16.8 \\
\hline 6 & Sequential spraying & 16.6 & 19.7 & 21.9 & 20.7 & 21.0 & 20.9 & 22.3 & 21.8 & 22.0 & 21.3 \\
\hline 7 & Control & 16.6 & 20.7 & 22.1 & 24.1 & 24.4 & 23.9 & 26.5 & 26.8 & 27.2 & 24.5 \\
\hline & Mean DI & 16.6 & 17.9 & 17.0 & 16.5 & 16.7 & 16.2 & 18.1 & 17.6 & 17.7 & \\
\hline
\end{tabular}

* Mean of 10 palms/treatment. "** See text for details of treatments. $a$ - C.D. $(P=0.01)$ for treatments: 4.1. $b$ - Analysed using the analysis of covariance technique taking the pre-treatment value as the covariate: Differences in treatment significant (C.D. $=9.5)$. 
Table 3. Leaf rot incidence-recurrence pattern in coconut palms under prophylactic control experiment (25 palms/category)

\begin{tabular}{|c|c|c|c|c|c|c|c|c|c|c|c|c|c|c|}
\hline \multirow[b]{3}{*}{ S.No. } & \multirow{3}{*}{$\begin{array}{c}\text { Round } \\
\text { Month/Year }\end{array}$} & \multicolumn{13}{|c|}{ Leaf rot incidence/recurrence in coconut palms under category } \\
\hline & & \multicolumn{4}{|c|}{ Treatment: Contaf pouring* } & \multicolumn{9}{|c|}{ Control** } \\
\hline & & 1 & 2 & 3 & 4 & 1 & 2 & 3 & 4 & 5 & 6 & 7 & 8 & 9 \\
\hline 1 & April 1996 & $\mathbf{O}$ & $\mathbf{O}$ & $\mathbf{O}$ & $\mathbf{O}$ & $\mathbf{O}$ & $\mathbf{O}$ & $\mathbf{O}$ & $\mathbf{O}$ & $\mathbf{O}$ & $\mathbf{O}$ & $\mathbf{O}$ & $\mathbf{O}$ & $\mathbf{O}$ \\
\hline 2 & September 1996 & $\mathbf{X}$ & $\mathbf{O}$ & $\mathbf{O}$ & $\mathbf{O}$ & $\mathbf{X}$ & $\mathbf{X}$ & $\mathbf{O}$ & $\mathbf{O}$ & $\mathbf{O}$ & $\mathbf{O}$ & $\mathbf{O}$ & $\mathbf{O}$ & O \\
\hline 3 & December 1996 & $\mathbf{O}$ & $\mathbf{O}$ & $\mathbf{O}$ & $\mathbf{O}$ & $\mathbf{X}$ & $\mathbf{X}$ & $\mathbf{O}$ & $\mathbf{O}$ & $\mathbf{O}$ & $\mathbf{O}$ & $\mathbf{O}$ & $\mathbf{O}$ & O \\
\hline 4 & May 1997 & $\mathbf{O}$ & $\mathbf{O}$ & $\mathbf{O}$ & $\mathbf{O}$ & $\mathbf{X}$ & $\mathbf{X}$ & $\mathbf{O}$ & $\mathbf{O}$ & $\mathbf{O}$ & $\mathbf{O}$ & $\mathbf{O}$ & $\mathbf{O}$ & O \\
\hline 5 & September 1997 & O & $\mathbf{X}$ & $\mathbf{O}$ & $\mathbf{O}$ & $\mathbf{X}$ & $\mathbf{X}$ & $\mathbf{X}$ & $\mathbf{O}$ & $\mathbf{O}$ & $\mathbf{O}$ & $\mathbf{O}$ & $\mathbf{O}$ & O \\
\hline 6 & December 1997 & $\mathbf{O}$ & $\mathbf{O}$ & $\mathbf{O}$ & $\mathbf{O}$ & $\mathbf{X}$ & $\mathbf{O}$ & $\mathbf{O}$ & $\mathbf{X}$ & $\mathbf{O}$ & $\mathbf{O}$ & $\mathbf{O}$ & $\mathbf{O}$ & O \\
\hline 7 & May 1998 & $\mathbf{O}$ & $\mathbf{X}$ & $\mathbf{O}$ & $\mathbf{X}$ & $\mathbf{O}$ & $\mathbf{X}$ & $\mathbf{O}$ & $\mathbf{O}$ & $\mathbf{X}$ & $\mathbf{X}$ & $\mathbf{O}$ & $\mathbf{X}$ & O \\
\hline 8 & September 1998 & $\mathbf{X}$ & $\mathbf{O}$ & $\mathbf{X}$ & $\mathbf{X}$ & $\mathbf{X}$ & $\mathbf{X}$ & $\mathbf{X}$ & $\mathbf{X}$ & $\mathbf{X}$ & $\mathbf{O}$ & $\mathbf{X}$ & $\mathbf{O}$ & $\mathbf{X}$ \\
\hline 9 & December 1998 & $\mathbf{O}$ & $\mathbf{X}$ & $\mathbf{X}$ & $\mathbf{O}$ & $\mathbf{X}$ & $\mathbf{X}$ & $\mathbf{X}$ & $\mathbf{O}$ & $\mathbf{X}$ & $\mathbf{X}$ & $\mathbf{O}$ & $\mathbf{X}$ & $\mathbf{X}$ \\
\hline \multicolumn{2}{|c|}{ Remarks } & \multicolumn{4}{|c|}{$\begin{array}{l}* \text { Leaf rot appeared in } 4 \text { out of } 25 \\
\text { palms (Mean D.I. at } 9^{\text {th }} \text { round: } 2.3\end{array}$} & \multicolumn{9}{|c|}{$* *$ Leaf rot appeared in 9 out of 25 palms (Mean D.I. at $9^{\text {th }}$ round: 20.8} \\
\hline
\end{tabular}

X: Lear rot-appearance in emerged spindles. $\mathrm{O}$ : Leaf rot- No appearance in emerged spindles. 